\title{
Ecological Monitoring of Acid Deposition in the Arctic Region
}

\author{
Olga Trubitsina*
}

Center for Environmental Studies, Northern (Arctic) Federal University, M.V. Lomonosov, North Dvina Bank, 17, Arkhangelsk, 163002 Russia

\begin{abstract}
The issue of atmospheric air pollution in the Arctic is of global nature and concerns the entire humanity. The fragile nature of high latitudes is extremely vulnerable to human impacts. The negative effects are caused not only by plants and factories located in the northern latitudes but also by far away plants in Central Europe, America, and Asia. As a result, pollutants migrating to the Arctic significantly affect the environmental situation in the northern regions of the planet. In order to improve the environmental situation in the Arctic, environment quality has to be managed properly in all regions of the world. This article is focused on the analysis of the situation in the Arctic region of Russia, namely in the North of the Russian Plain. Starting from the 1980's, Russia has conducted environmental monitoring of the snow cover to determine critical pollutant loads on natural ecosystems across the country. A large amount of data has been accumulated allowing to carry out an in-depth analysis of the pollution of atmospheric precipitations and snow cover with acid-forming compounds. This article summarizes the results of research conducted from 1982 to 2013, including: 1) pollutant emission trends compared to available atmospheric air monitoring data, 2) spatial distribution of acidified precipitation occurrences, 3) neutralization probability, 4) calculation of sulphur deposition loads compared to the reference values proposed as critical loads by the European Monitoring and Evaluation Program (EMEP)
\end{abstract}

Keywords: Air Pollution, Acid Depositions, Arctic, Precipitation, Critical Loads, The North of the Russian Plain.

\section{INTRODUCTION}

Most experts in many countries of the world are now confident that the causes of acid rain and the response of deposition to reductions in emissions are well understood (National... 2005). Internationally the "Cooperative programme for monitoring and evaluation of long-range transmission of air pollutants in Europe" (EMEP) was launched in 1977 as a response to the growing concern over the effects on the environment caused by acid deposition (EMEP... 2001). Starting from the 1980 's, Russia has conducted environmental monitoring of the snow cover to determine critical pollutant loads on natural ecosystems across the country. This article is focused on the analysis of the situation in the Russian Arctic region with surrounding territories, namely in the North of the Russian Plain. The area spans a vast territory $\left(36-64^{\circ}\right.$ E. and $59-70^{\circ}$ N.) (Fig. 1) and includes landscape zones such as Subarctic (with Arctic, Typical, Southern Tundra, Forest Tundra subzones) and Taiga, or Boreal, zone (with Northern, Middle, and Southern Taiga subzones). The region is one of Russia's major suppliers of fuel and energy and contains significant reserves of natural resources which are used extensively for production purposes.

The distribution of the industry sectors across the North of the Russian Plain is as follows: 1) the north-western zone

*Address correspondence to this author at the Center for Environmental Studies, Northern (Arctic) Federal University named after M.V. Lomonosov, North Dvina Bank, 17, Arkhangelsk, 163002 Russian,

E-mail: test79@yandex.ru is dominated by the pulp-and-paper industry, heat and power generation, machine building, metal processing (Arkhangelsk, Severodvinsk, Novodvinsk, Onega); 2) the southeastern and south-western parts have more metallurgy, cogeneration, chemical, wood-processing plants (Cherepovets, Vologda, Sokol, Syktyvkar, Ukhta); 3) the main industries in the north-eastern zone are oil production, co-generation, coal, and construction industries (Naryan Mar, Vorkuta) (Trubitsina 2002; Trubitsina \& Shvartsman 2007).

These are among the least environmentally friendly industries. Their emissions and effluents negatively impact the fragile nature of the North. In view of this, it seems important to analyse the condition of ambient air and precipitations in the areas affected by these facilities.

Table 1 compiled from data provided by the Northern Hydrometeorological Office shows the distribution of measured precipitation components depending on the possible pollution source. The numbers for the respective industries indicate the approximate place in the series of the main elements emitted by them to the environment.

Ranked by weight percentage of the total amount of emissions, the most common pollutants making part of atmospheric precipitations around the main sources of pollution in the North of the Russian Plain are $\mathrm{SO}_{4}{ }^{2-}, \mathrm{CI}^{-}, \mathrm{NO}_{3}{ }^{-}$. These ions can cause formation of acid deposition in the area in question (Trubitsina 2013). Emissions of sulfur dioxide are responsible for $60-70 \%$ of the acid deposition that occurs globally. More than $90 \%$ of the sulfur in the atmosphere is of human origin. Some $95 \%$ of the elevated levels of nitrogen oxides in the atmosphere are the result of human activities. 


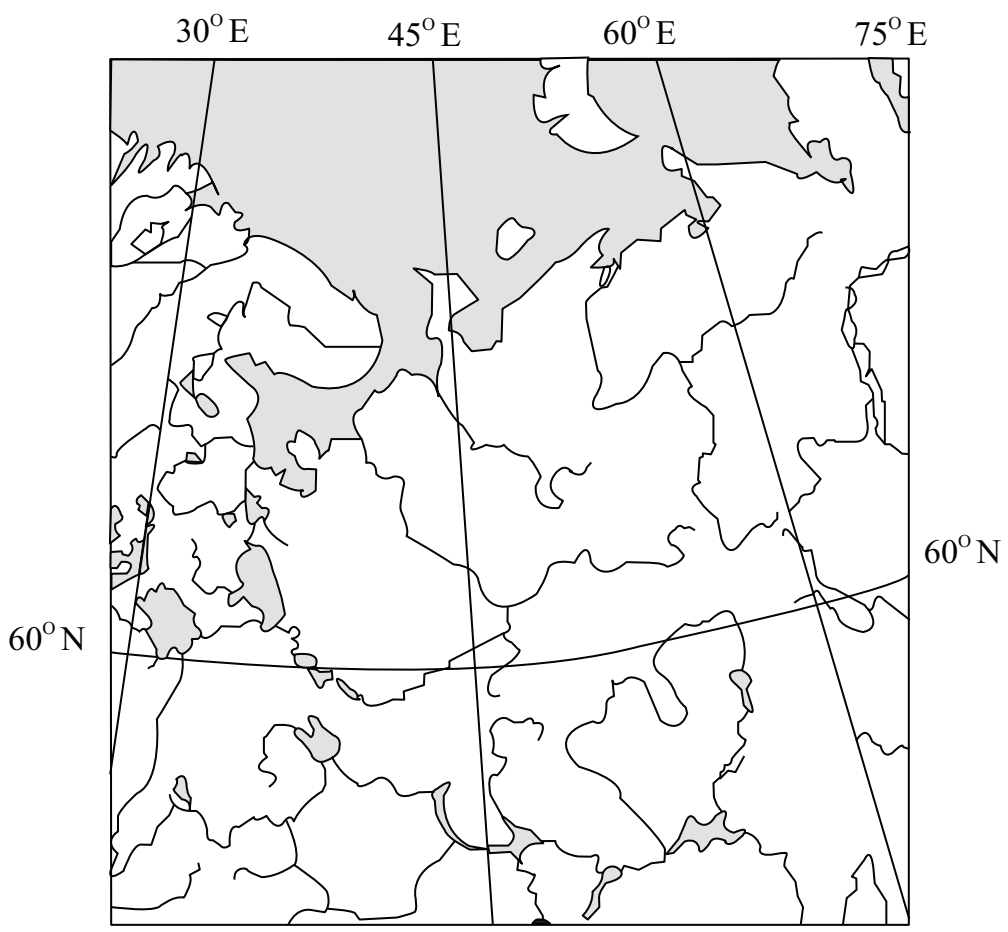

Fig. (1). The geography map of the North Russian plain.

Table 1. Dominating ingredients of atmospheric precipitations in the North of the Russian Plain in areas of major pollution sources.

\begin{tabular}{|c|c|c|c|}
\hline \multirow{2}{*}{ The Respective Industries } & \multicolumn{3}{|c|}{$\begin{array}{l}\text { Place in the Series of the Main Elements Emitted by the Respective Industries to } \\
\text { the Environment }\end{array}$} \\
\hline & $\mathrm{SO}_{4}{ }^{2-}$ & $\mathbf{C I}^{-}$ & $\mathrm{NO}_{3}^{-}$ \\
\hline The pulp-and-paper industry & 1 & 3 & 6 \\
\hline Metallurgy & 1 & 2 & 7 \\
\hline Chemical plants & 2 & 1 & 4 \\
\hline Machine building, metal processing & 2 & 1 & 6 \\
\hline Co-generation & 2 & 1 & 6 \\
\hline
\end{tabular}

The remaining $5 \%$ comes from several natural processes. Finally, the concentrations of both nitrogen oxides and sulfur dioxides are much lower than atmospheric carbon dioxide which is mainly responsible for making natural rainwater slightly acidic. However, these gases are much more soluble than carbon dioxide and therefore have a much greater effect on the $\mathrm{pH}$ of the precipitation (Pidwirny 2006).

\section{DATA ANALYSIS METHOD}

The electronic data bank was processed using statistical and graphical methods. The data analysed includes emissions from stationary industrial sources that took place in the area in question over $1988-2013$, annual snow survey data from 42 stations over 1982 - 2003, as well as monthly precipitation data recorded at 13 stations over $1990-2003$. These were analysed as weighted average concentrations of the main precipitation components for each month. As a result of the data processing it was determined that the occurrence class frequency of $\mathrm{pH}(\%)$ values ranged between 4.0 and 8.0 with an increment of 0.4 . For the calculation of annual average weighted $\mathrm{pH}$ values of atmospheric precipitation samples, it was taken into account that $\mathrm{pH}=-\lg \left[\mathrm{H}^{+}\right]$and, therefore, it was not possible to obtain its average by the simple arithmetic way. Therefore, the $\mathrm{pH}$ values were converted to hydrogen ion concentrations and the method adopted by the Voyeykov Main Geophysical Observatory was used, with consideration of the amount of precipitations that fell out for each ingredient:

$$
\bar{C}=\frac{\sum_{i=1}^{n} C_{i} \cdot q_{i}}{\sum_{i=1}^{n} q_{i}},
$$


where $\bar{C}$ is the weighted average concentration of component $\left(\mathrm{H}^{+}\right)$in precipitations, $\mathrm{mg} / \mathrm{l} ; \mathrm{Ci}$ is component concentration in the sample, $\mathrm{kg} / \mathrm{l} ; q i$ is the amount of precipitations (in the month), $\mathrm{mm} ; n$ is the number of precipitation samples (months).

The total Air Pollution Index (API) was calculated in order to evaluate the degree of atmospheric air pollution in the industrial centres in the North of the Russian Plain. This is a composite indicator that considers several impurities. The API value is calculated from annual average concentrations $\left(q_{\text {av. } i}\right)$. The indicator thus characterizes the level of chronical, long-term air pollution. According to the existing evaluation methods, the level of pollution is deemed to be very high if the total API exceeds 14, high if $14>$ API $>7$, elevated at $7>\mathrm{API}>5$, low at $\mathrm{API}<5$.

The API for a single substance was calculated using the formula:

$J_{i}=\left(q_{a v . i} / M A C s\right)^{K i}$

where $K_{i}=0.86 ; 1.0 ; 1.3 ; 1.7$, respectively for hazard classes 4, 3, 2, and 1. MACs is Maximum Allowable Concentrations.

The composite API which considers $m$ substances present in the atmosphere was calculated using the formula:

$$
J_{(m)}=\sum_{i=1}^{m}\left(q_{\tilde{n} \partial .} / M A C s\right)^{k_{i}}
$$

$J_{(m)}$ was calculated for $m=5$, i.e. from five highest concentrations of substances contributing the most to the overall air pollution. The selection of $m$ substances to calculate $J_{(m)}$ is done by first compiling a decreasing variational series of $J_{i}$ values.

Daily-average and maximum short-term exposure limits (MACs) were used to evaluate the state of air pollution in the cities. Annual average values were compared with the daily average MACs specified by the Russian Ministry of Public Health.

The procedure developed in Russia at the Global Climate and Ecology Institute of the Hydromet Agency and RAS by V.N. Vasilenko, I.M. Nazarov and Sh.D. Fridman (1992) was used to calculate neutralization of acidified precipitations, sulphur fallout loads (Vasilenko et al., 1992). Neutralization of acidified precipitations is characterized by factor $\delta$ which is equal to the percentage of effective strong acids, and the parameter $1-\delta$ is the percentage of neutralized strong acids in precipitations: If $0<\Sigma^{+} / \Sigma^{-}<1$, the formula $\delta=1-\sum z_{j}\left[c_{j}^{z_{j+}}\right] / \sum z_{i}\left[c_{i}^{z_{i-}}\right]$

If $\sum^{+} / \Sigma^{-} \geq 1$, the formula $\delta=0$

where $\left[{ }_{C_{j, i}}\right.$ ] are molar concentrations of the main anions and cations; $Z_{j, i}$ are their valences. At $\mathrm{pH}=4.5-5.0$ the relation (4) is satisfied to within $15 \%$.
Long-term observations of the composition of atmospheric precipitations show that it is sufficient to consider only the main anions and cations i.e.: $\mathrm{SO}_{4}{ }^{2-}, \mathrm{NO}_{3}{ }^{-}, \mathrm{CI}^{-}, \mathrm{NH}_{4}{ }^{+}$, $\mathrm{Ca}^{2+}, \mathrm{Mg}^{2+}, \mathrm{Na}^{+}, \mathrm{K}^{+}$.

The winter sulphur fallout rate $U_{s}, \mathrm{~kg} / \mathrm{km}^{2} * d a y$ was determined according to the relation:

$U_{s}=C P / N$,

where $C$ is sulphate sulphur concentration in snow cover present for $N$ days; $P$ is the total amount of atmospheric precipitations over $N$ days; $Q=C P$ is the sulphate sulphur amount in snow.

The actual pollutant load per year $U_{a c t .}, \mathrm{kg} / \mathrm{km}^{2} *$ year was determined as follows:

$U_{\text {act.. }}=P_{w} C_{w}+P_{s} C_{s}=C_{w}\left(P_{w}+\frac{1}{k} * P_{s}\right)$,

where $P_{w}, C_{w}, P_{s}, C_{s}$ are the amounts of atmospheric precipitations and average pollutant concentrations in atmospheric precipitations during the winter and summer periods; $k=C_{w}$ / $C_{s}$

The design sulphur deposition loads were compared to the EMEP critical loads using the following relation:

$\Delta U_{i}=U_{c r . i}-U_{a c t . i}$ для $U_{c r i}-U_{a c t . i}>0$,

where $U_{c r . i}$ is critical load of $i$-th ingredient on natural ecosystems.

If it is $U_{c r . i}-U_{a c t . i}>0$ it means that natural ecosystems in the territory are not affected by anthropogenic stress. For territories where $U_{a c t . i}^{>} U_{c r . i}$ the regional ecological condition becomes critical and leads to degradation of ecosystems. The critical load levels are taken from the maps published by the EMEP working group for the region.

\section{POLLUTANT EMISSION TRENDS COMPARED TO AVAILABLE ATMOSPHERIC AIR MONITORING DATA}

The dynamics of pollutant emissions from stationary sources were evaluated according to data from statistical reports for the cities in the North of the Russian Plain. It was found (Fig. 2) that the rise in total pollutant emissions over 1988 - 1991 was replaced by a downward trend until 2013. Only a third of the total reduction in emissions to atmosphere was due to environment protection efforts, while two thirds were mainly a result of the decline in industrial manufacturing. Similar trends are typical for all cities in the North of the Russian Plain.

The percentage composition of the main polluting components in the air has changed during the period from 1992 to 2013. For instance, in Arkhangelsk Oblast (Fig. 3), the percentage of sulphur dioxide rose $16 \%$ to nearly $1 / 2$ of total emissions over 1992-2003. The increase occurred despite the drop in total emissions from stationary sources. However, the total amount decreased by 283.7 thousand tons per year, while the amount of sulphur dioxide decreased by 37.2 


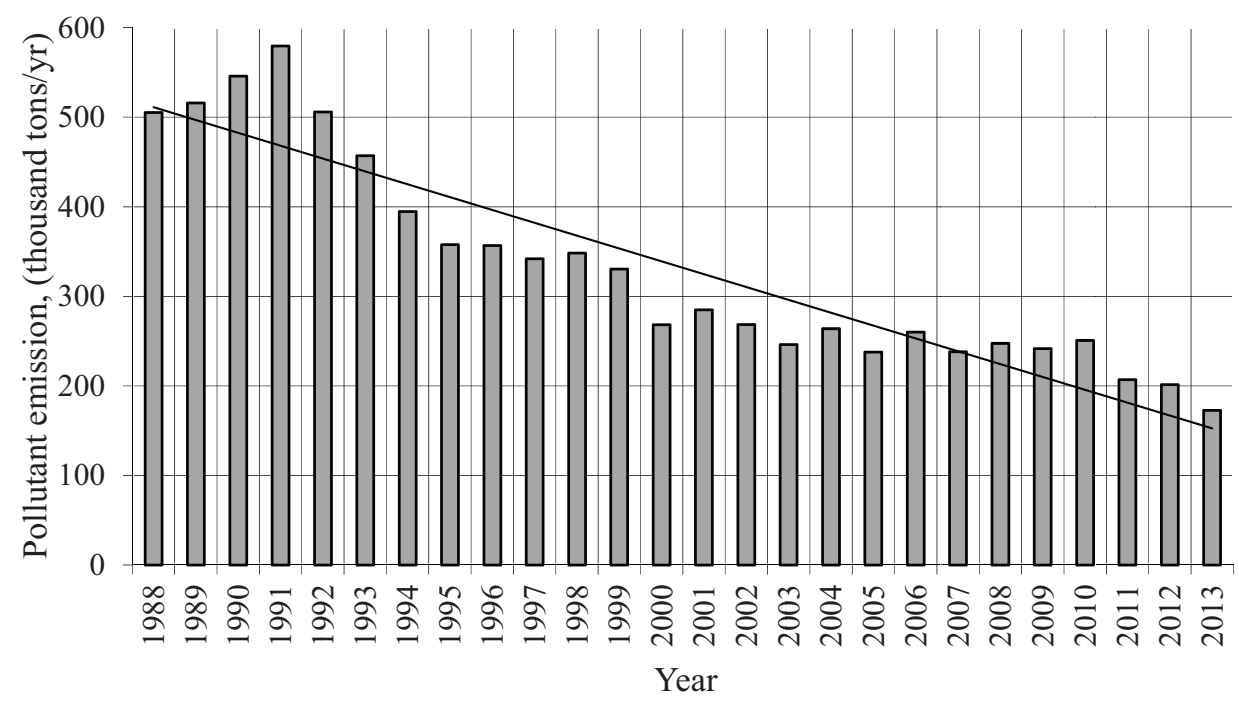

Fig. (2). Atmospheric pollutant emission trend for Arkhangelsk Oblast, in thousand tons.

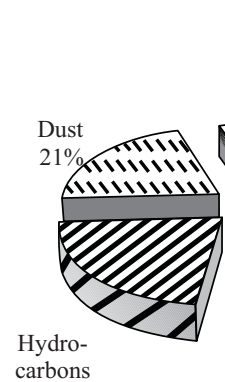

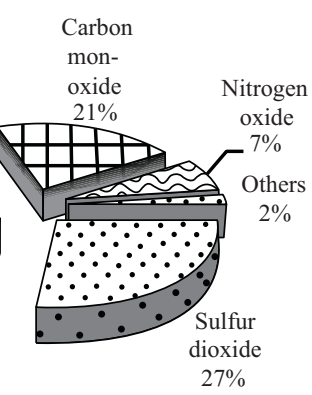

A

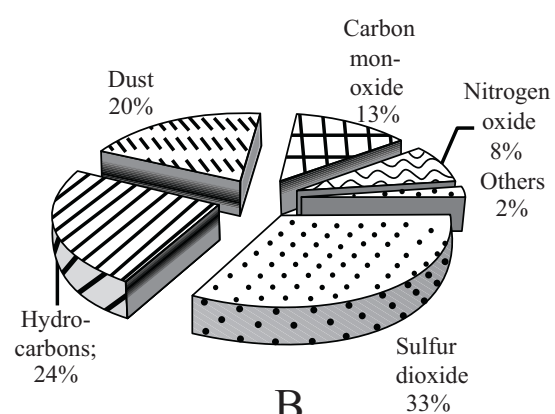

$\mathrm{B}$

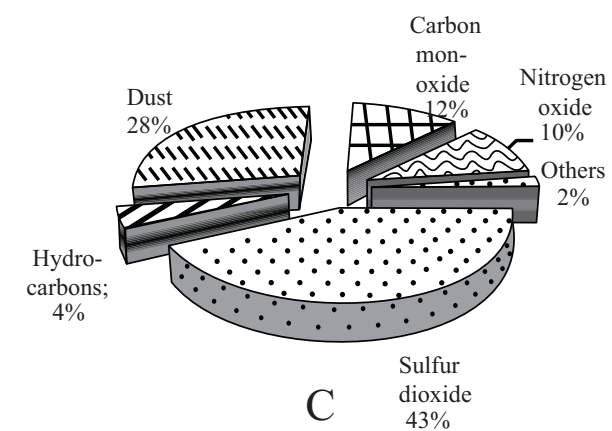

Fig. (3). Atmospheric pollutant emissions in Arkhangelsk Oblast in 1992 (A), 1999 (B) and 2003 (C), \%.

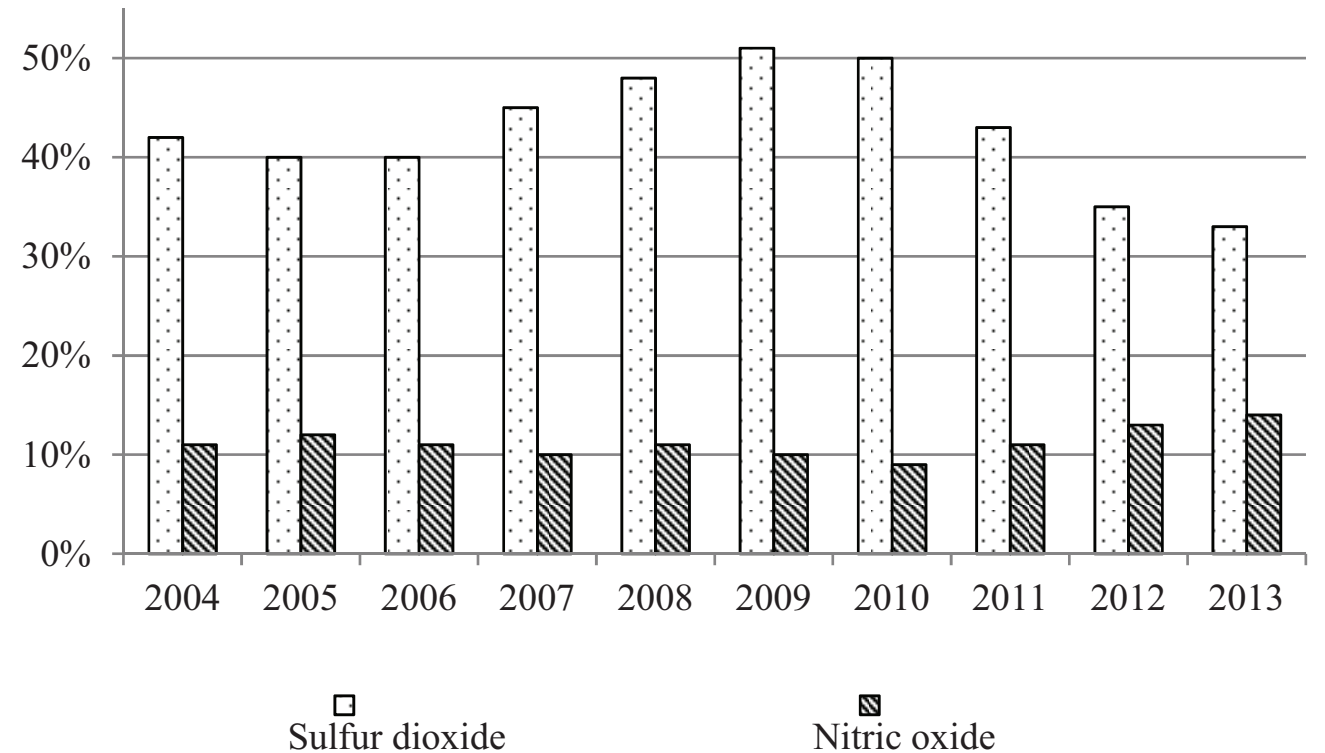

Fig. (4). Variations in emissions of sulphurous anhydride and nitrogen oxide during $2004-2013$.

thousand tons per year. Also the percentage of nitrogen oxides rose by $3 \%$ in the same period. The absolute total emissions dropped from 36 thousand tons per year to 23 thousand tons per year. Hydrocarbons became a minor contributor as their percentage in the overall pollutant emissions fell $16 \%$. The annual variations in the percentage of acid-forming compounds in emissions from stationary sources during the consequent years 2004-2013 are shown in Fig. (4). 
Table 2. Predominant pollutants in cities in the North of the Russian Plain.

\begin{tabular}{|c|c|}
\hline City & $\begin{array}{c}\text { Substances Contributing the Most to the Overall } \\
\text { Air Pollution of City }\end{array}$ \\
\hline Arkhangelsk & $\begin{array}{l}\text { Methyl mercaptan, carbon disulfide, formaldehyde, } \\
\text { dust, benz(a)pyrene }\end{array}$ \\
\hline Novodvinsk & $\begin{array}{l}\text { Methyl mercaptan, carbon disulfide, formaldehyde, } \\
\text { dust, benz(a)pyrene }\end{array}$ \\
\hline Severodvinsk & $\begin{array}{l}\text { Formaldehyde, nitrogen dioxide, carbon monoxide, } \\
\text { benz(a)pyrene, dust }\end{array}$ \\
\hline Koryazhma & $\begin{array}{l}\text { Methyl mercaptan, nitrogen dioxide, hydrogen sul- } \\
\text { fide, dust, sulfur dioxide }\end{array}$ \\
\hline Vologda & $\begin{array}{l}\text { Formaldehyde, benz(a)pyrene, dust, nitrogen diox- } \\
\text { ide, carbon monoxide }\end{array}$ \\
\hline Cherepovets & $\begin{array}{l}\text { Carbon bisulfide, formaldehyde, dust, ammonia, } \\
\text { benz(a)pyrene }\end{array}$ \\
\hline Syktyvkar & $\begin{array}{c}\text { Methyl mercaptan, dust, formaldehyde, carbon mon- } \\
\text { oxide, benz(a)pyrene }\end{array}$ \\
\hline Ukhta & $\begin{array}{l}\text { Methyl mercaptan, carbon monoxide, nitrogen diox- } \\
\text { ide, dust, benz(a)pyrene }\end{array}$ \\
\hline Vorkuta & $\begin{array}{l}\text { Formaldehyde, nitrogen dioxide, carbon monoxide, } \\
\text { dust, benz(a)pyrene }\end{array}$ \\
\hline
\end{tabular}

Thus, in the early $21^{\text {st }}$ century the reduction in the overall emissions occurred while the percentage of sulphurous and nitrogen compounds in ambient air increased mainly in the cities of the Arkhangelsk agglomeration. The average percentage of sulphur dioxide in emissions during 1992-2013 was $41 \%$, nitrogen oxide $-11 \%$. A relatively stable, high amount of similar pollutants is emitted by stationary sources in the industrial centres of Vologda Oblast (Chere-povets) and Komi Republic (Vorkuta).

With regard to comparison between the emission data and the atmospheric air pollution monitoring data, particular attention was given to the Atmosphere Pollution Index (API). It was considered that air samples in the monitoring network were tested not only for the content of solids, sulphur dioxide, nitrogen oxide, carbon oxide, hydrocarbons, but also for specific substances related to the particular industrial processes (Table 2). For the area in question, these substances include methyl mercaptan, formaldehyde, benz(a) pyrene, carbon disulphide, dust.

The analysis of the API in the North of the Russian Plain shows that a very high level during this whole period of time had been observed in Cherepovets, reaching its maximum point in 2003 (API = 19.8). In the cities of Arkhangelsk Oblast with its pulp-and-paper industry, during $1990-1998$ API was > 14, also indicating a very high level of air pollution. The API fell in Arkhangelsk, Novodvinsk, and Koryazhma in 1999 due to the fact that the daily-average and maximum short-term MACs for methyl mercaptan were raised from $9 * 10^{-6} \mathrm{mg} / \mathrm{m}^{3}$ to $1 * 10^{-4} \mathrm{mg} / \mathrm{m}^{3}$, which affects the accuracy of the observation series. [Mapping and Modelling of Critical Loads for Nitrogen: a Workshop Report (1995)]. However, despite the revision of MAC for methyl mercaptan, the atmospheric air pollution level in the Arkhangelsk rose by the year 2013, indicating a high level of air pollution according to the monitoring data.

In 2013, a high level of atmospheric air pollution was observed in the cities from the north-western zone (Arkhangelsk agglomeration). A very high level was observed in the south-eastern zone (Cherepovets). Despite the reduction in the total emissions (almost by a half) from stationary sources, the atmospheric air pollution level according to the monitoring data practically didn't change.

The most reliable indicator of atmospheric air condition is the snow cover which accumulates pollutants over a comparatively long period of time. Snow deposits can be tested to determine pollutants which cannot be determined by direct measurements or from calculation data for dust and gas emissions. A snow survey allows to evaluate pollutant amounts in the snow cover. The survey is used widely in the North of the Russian Plain also due to the fact that this territory has a stable snow cover.

Data on pollutant content in the snow cover can be used to estimate both global and regional atmospheric pollution across large territories of the country during the winter period and determine the pollutant distribution area in industrial centres.

The analysis of the snow surveys carried out at 42 stations during $1982-2003$ shows that the prevailing class of $\mathrm{pH}$ values for the snow cover in this area is between 6.0 and $6.4(27 \%)$. However, the total frequency of acid value classes $(\mathrm{pH}<5.6)$ is $24.1 \%$, dominated by the low-acid precipitation class $(\mathrm{pH}=5.2-5.6(15.5 \%)$. For the analysis of annual average $\mathrm{pH}$ values in samples of atmospheric precipitations at 14 stations mainly located in the industrial centres of the North of the Russian Plain during 1990 - 2003, it should be noted that the prevailing class of $\mathrm{pH}$ values is 5.2 to $5.6(23.2 \%)$. The total frequency of acidified fallouts was $45.1 \%$. No atmospheric precipitations with $\mathrm{pH}>7.2$ were observed (Fig. 5).

The data on precipitations for individual months with averaged annual $\mathrm{pH}$ values i.e. calculations of weighted average values are more accurate. However, compared to annual average $\mathrm{pH}$, the weighted annual average values are not so much different. Also, the prevailing class of precipitation $\mathrm{pH}$ values is in the range of 5.2 to 5.6 (20.7\%, which is 2.5 $\%$ lower than the annual average). The frequency of the $\mathrm{pH}$ class between 4.8 and 5.2 increases (by $3.1 \%$ ), and there is a slight decrease in the percentage of the ranges 4.4 to $4.8(1.2$ $\%)$ and 4.0 to $4.4(0.6 \%)$. In general, the total frequency of weighted annual average acid fallouts is $43.9 \%$.

Thus nearly a quarter $(24.1 \%)$ of snow cover samples tested during 1982 - 2003 were acidified, while in atmospheric precipitations in the North of the Russian Plain during 1990 - 2003, acidified fallouts were encountered in almost half of the cases $(45.1 \%$ without considering the amount of 


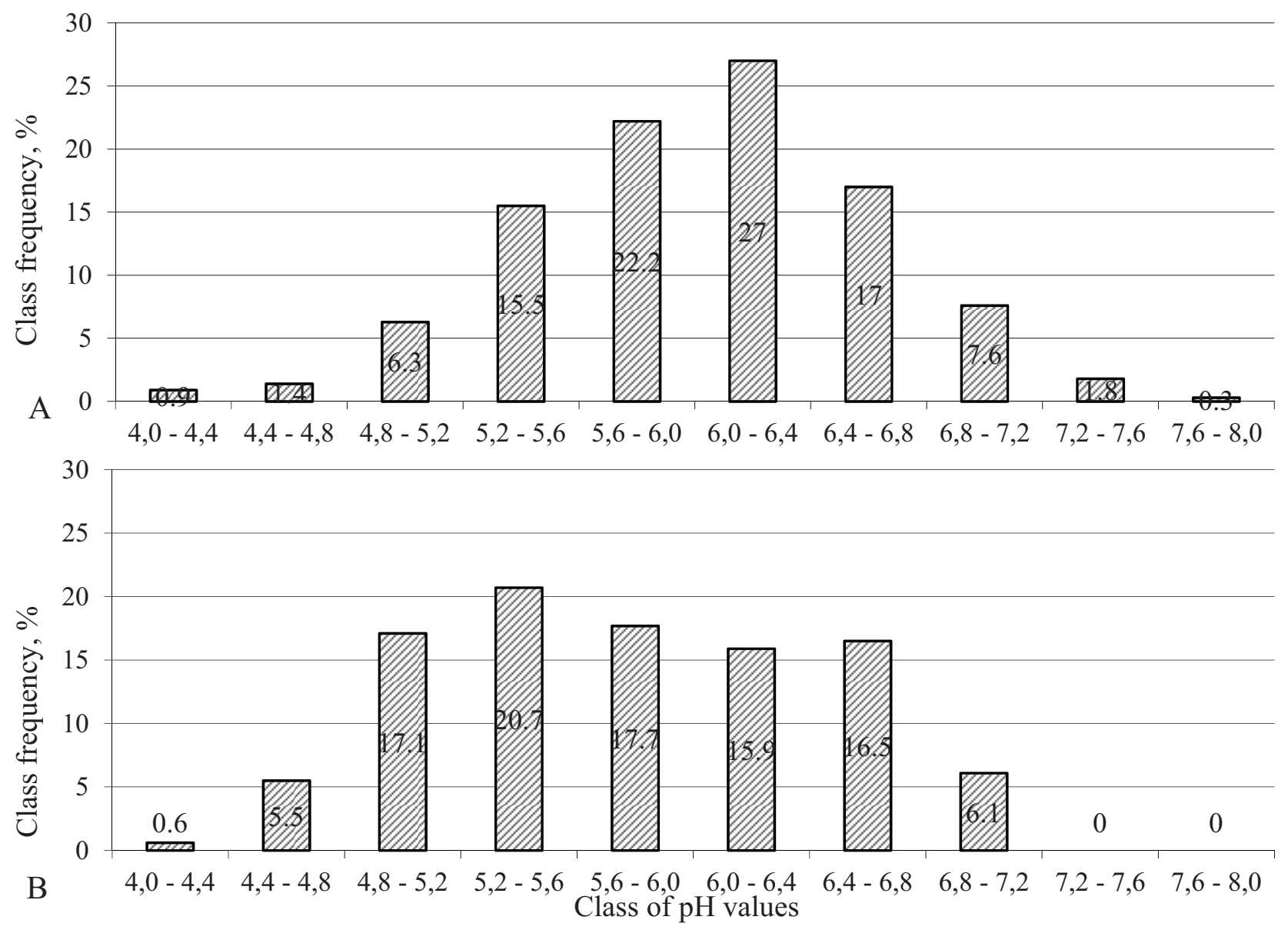

Fig. (5). Distribution of pH values in snow cover at 42 stations in the North of the Russian Plain during 1982 - 2003 (A), in atmospheric precipitations at 14 stations during $1990-2003$ (B), \%.

precipitations, $43.9 \%$ considering the amount of precipitations) (Trubitsina 2013). It is important to understand during the winter the acidic deposits can buildup in the snowpack. With the arrival of spring, snowpack begins to melt quickly and the acids are released over a short period of time at concentrations 5 to 10 times more acidic than rainfall (Pidwirny 2006).

\section{SPATIAL DISTRIBUTION OF ACIDIFIED PRECIPI- TATIONS IN FREQUENCY DETECTION}

According to the determination of deposition balance, in more than half of individual administrative units of Russia, $50 \%$ to $90 \%$ by weight of fallouts in the regions is due to transborder transfer and transfer from other regions within the country. The share of fallouts due to local sources in the overall deposition balance of the administrative territories usually is not higher than $30 \%$. The rest of fallouts are due to long-distance atmospheric transport from other regions of the country and transborder transport. According to the monitoring data of the Russian Hydrometeorological Agency, high sulphur deposition levels $550-750 \mathrm{~kg} / \mathrm{km}^{2}$ year and nitrogen compound totals $370-720 \mathrm{~kg} / \mathrm{km}^{2}$ year covering significant areas (first thousands of $\mathrm{km}^{2}$ ) are observed in densely populated and industrial regions of the country. Local areas (up to $1.000 \mathrm{~km}^{2}$ ) with sulphur fallout rate $1500-300 \mathrm{~kg} / \mathrm{km}^{2}$. year can be seen in the near wake of smelteries, refineries, large district power plants, and large cities.

The North of the Russian Plain is a part of Russia's Northern Economic District. Here the distribution of acidforming compounds during the period when their percentage in industrial emissions increased every year was as follows: the atmospheric sulphur deposition load (in sulphur units) was the highest in Cherepovets $\left(1000 \mathrm{~kg} / \mathrm{km}^{2}\right.$ year), the Arkhangelsk agglomeration $\left(600 \mathrm{~kg} / \mathrm{km}^{2}\right.$ year), Vorkuta $(300-$ $400 \mathrm{~kg} / \mathrm{km}^{2}$ year). Nitrate nitrogen fallouts are also associated with Cherepovets $\left(300-400 \mathrm{~kg} / \mathrm{km}^{2}\right.$ year $)$, the Arkhangelsk agglomeration $\left(100-200 \mathrm{~kg} / \mathrm{km}^{2}\right.$ year $)$, Vorkuta $(100$ $-150 \mathrm{~kg} / \mathrm{km}^{2}$ year).

Thus, the highest acid-forming loads are characteristic of three industrial zones in the North of the Russian Plain: north-western (Arkhangelsk agglomeration), south-western (Cherepovets), north-eastern (Vorkuta) (Trubitsina 2013).

\section{NEUTRALIZATION PROBABILITY}

It is well known that there are basic differences in the negative impacts of nitrogen and sulphur loads on the 
environment. Nitrogen compounds are involved intensively in the vegetation metabolism processes, their excessive amounts affect seriously land surface and water ecosystems. The negative effects of sulphur fallouts (more than $90 \%$ of which falls out in the form of sulphates) are associated with acid action. Therefore, the evaluation of environmental impact by atmospheric sulphur fallouts requires additional analysis of the ion composition of precipitations to determine the sulphuric acid neutralization effect. When this effect takes place, it lowers the load on the environment and biota. Such analysis for a number of areas in central Russia showed that precipitations were not acidified even when the critical sulphur loads were significantly exceeded. Acid can be neutralized by alkaline and alkaline-earth elements present in atmospheric precipitations in amounts exceeding the content of acid-forming anions.

In the atmospheric air in the North of the Russian Plain, the acid-forming compounds are sulphates and chlorides. Nitrates are of secondary importance. Their predominant spatial position is distributed as follows: chlorides determine the lower $\mathrm{pH}$ level mostly in the littoral areas, while sulphates dominate elsewhere.

The ecological significance of acid-forming atmospheric fallout loads in the North of the Russian Plain was evaluated using data from the network of atmospheric precipitation and snow cover monitoring stations.

The percentage of effective strong acids $\delta$ was calculated according to the monthly data of atmospheric precipitation monitoring using the 21-st century transition period as an example (cold and warm periods of $1999-2000$ ).

For the analysis of $\delta$ calculation results for atmospheric precipitations, it should be noted that occasionally $\delta>0$, which means that precipitations are likely to contain effective strong acids that would not be neutralized. However, their amount does not exceed $15 \%$ of potential acid formation. For stations in the north-western industrial zone, the highest percentage of effective strong acids (15\%) occurs in the beginning of the warm period (April), for stations in the north-eastern (Naryan Mar) and south-western (Cherepovets) zones it happens at the end of the warm period (October). The calculation of $\delta$ for fallouts during the winter period of 1999 - 2000 according to the snow survey monitoring data (mol/l) shows the highest percentage of effective strong acids $(17 \%)$ in the north-eastern zone of the northern Russian Plain.

\section{COMPARISON BETWEEN ACTUAL AND CRITICAL LOADS FOR SULPHUR}

The critical loads concept is based on the idea of threshold effect that environmental hazards produce on ecosystems. The critical load is a maximum acceptable concentration of a pollutant whose annual atmospheric input to the ecosystem over a long period of time (50-100 years) will not cause irreversible changes to its structure and functions. This indicator characterizes the assimilation potential of ecosystem and is analogous to the reference dose for pollutants, a general accepted impact standard in environmental risks assessment (Sustainable... 2013). The concept of critical loads is now widely accepted as a basis for developing optimised air pollutant abatement strategies within the United Nations Economic Commission for Europe (UNECE) Convention on Long Range Transboundary Air Pollution. It was the first used in the negotiation of the Protocol on Further Reduction of Sulphur Emissions adopted in June 1994 (Mapping... 1995).

Nilsson and Grennfelt originally characterized a critical load as "the quantitative estimate of an exposure to one or more pollutants below which significant harmful effects on specified sensitive elements of the environment do not occur according to present knowledge" (Nilsson \& Grennfelt 1988).

For most Russian ecosystems critical loads for sulphur are $<500$ eq $\mathrm{yr}^{\prime}$ and only in calcerous soils of Middle Asia and Central Yakutia are the values $>2000$ eq ha-' yr'. Consequently, taking into account acidifying effect of $\mathrm{S}$ and $\mathrm{N}$ depositions, ecosystems of middle Asia are not sensitive to acidification (CL values $>2000$ eq yr1). Moderate sensitivity can be shown for ecosystems of boreal and sub-boreal north humid forests of European Russia, the Far East and South Siberia. In contrast, most of the area situated north of 60 grad. latitude and east of the River Enisey has the lowest values $\left(<200\right.$ eq ha ' $\left.\mathrm{yr}^{\prime}\right)$. These calculations have been used as the basis of various abatement strategy scenarios (Bashkin \& Kozlov 1995).

Based on the critical load maps for atmospheric sulphur fallouts, built by the EMEP working group, and the snow cover monitoring network data from the Northern Hydrometeorological Office, maps were prepared for exceeded critical load levels of atmospheric sulphur fallouts using the EMEP grid squares. The annual average load values were averaged for each square. The critical load levels of atmospheric sulphur fallouts are exceeded for forest and water ecosystems in the following conditions: $\frac{\text { Act.load_level }}{\text { Crit.load_level }} \geq 1$. The map analysis showed that these ratios were lower than one in almost all the cases. An exception to that were littoral areas where these ratios were higher than one, pointing to a significant role of natural sulphur input there. The map showing the ratios of observed actual loads to critical loads is provided in Fig. (6).

Table 3 means that: 1). The region's dominating acidforming ingredient is chlorine. The number of observed ratios $\mathrm{SO}_{4}{ }^{2-} / \Sigma^{-}$and $\mathrm{CI}^{-} / \Sigma^{-}$is approximately equal. At the same time, 7 out of 10 observed acidified precipitation cases are due to chlorine; 2) Almost all acidification cases are characterized by low values of $\Sigma^{+} / \Sigma^{-}$i.e. 0.83 to 1.04 .

Comparison between sulphur deposition loads and reference values of critical EMEP loads (Table 4) shows that natural ecosystems are generally not subjected to anthropogenic stress, with the exception of coastal areas, a local point near the Pechora river $\left(U_{c r . i}-U_{a c t . i}<0\right)$, and the Northern Dvina mid-stream area having the lowest values of $\Delta U_{i}(0$ $\left.<U_{c r . i}-U_{a c t . i}<10\right)$. 


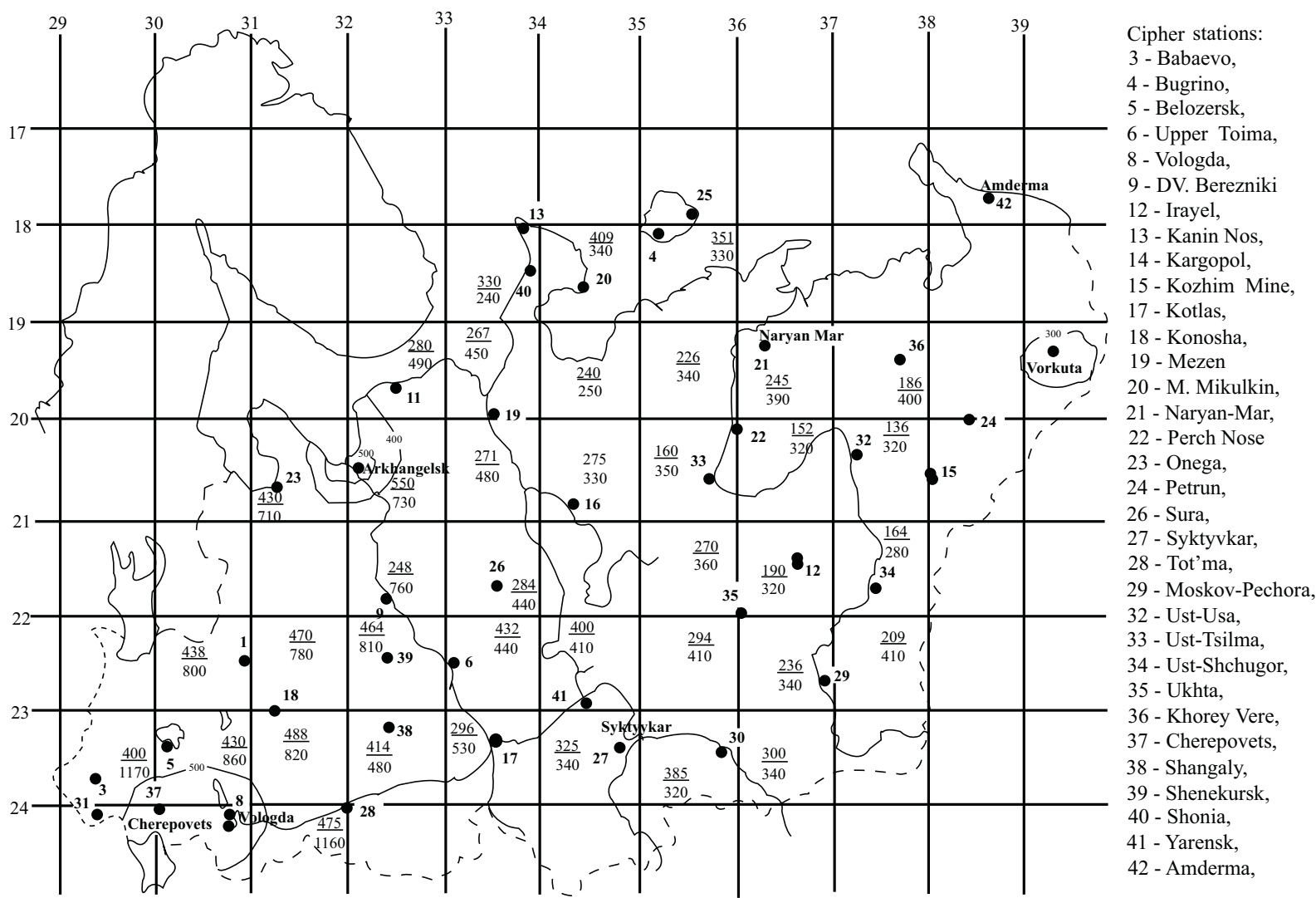

Fig. (6). Map of actual atmospheric sulphur fallout load to critical load ratio for forest and water ecosystems.

Table 3. Basic data on sulphur fallout rate, acidification level of winter precipitations, their ion composition according to snow cover pollution monitoring data for $1999-2000$.

\begin{tabular}{|c|c|c|c|c|c|c|c|c|}
\hline Cipher & Station & Us, $\mathbf{k g} / \mathbf{k m}^{2} *$ year & $\Sigma^{+} / \Sigma^{-}$ & $1-\Sigma^{+} / \Sigma^{-}$ & pH & $\mathrm{C}\left[\mathrm{H}^{+}\right], \mathrm{mol} / \mathrm{l} \mathbf{1 0}^{-6}$ & $\mathrm{SO}_{4}{ }^{2-} / \Sigma^{-}$ & $\mathrm{CI}^{\prime} / \mathrm{\Sigma}^{-}$ \\
\hline 5 & Belozersk & 499 & 1.03 & 0 & 5.09 & 2.14 & 0.22 & 0.41 \\
\hline 6 & Upper Toima & 432 & 1.16 & 0 & 5.55 & 1.35 & 0.3 & 0.51 \\
\hline 9 & Bits. Bereznik & 248 & 1.44 & 0 & 6.44 & 0.36 & 0.15 & 0.78 \\
\hline 12 & Irayel & 195 & 1.25 & 0 & 5.82 & 1.51 & 0.44 & 0.35 \\
\hline 15 & Kozhim Mine & 548 & 1.4 & 0 & 6.05 & 0.89 & 0.41 & 0.44 \\
\hline 21 & Naryan-Mar & 245 & 1.05 & 0 & 5.61 & 0.37 & 0.52 & 0.35 \\
\hline 22 & Okunev Nose & 208 & 0.88 & 0.12 & 5.5 & 3.16 & 0.45 & 0.29 \\
\hline
\end{tabular}


Table 3. contd...

\begin{tabular}{|c|c|c|c|c|c|c|c|c|}
\hline Cipher & Station & Us, $\mathbf{k g} / \mathbf{k m}^{2 *}$ year & $\Sigma^{+} / \Sigma^{-}$ & $1-\Sigma^{+} / \Sigma^{-}$ & pH & $\mathrm{C}\left[\mathrm{H}^{+}\right], \mathrm{mol} / \mathrm{l} \mathbf{1 0}^{-6}$ & $\mathrm{SO}_{4}{ }^{2-} / \Sigma$ & $\mathrm{CI} / \Sigma^{-}$ \\
\hline 23 & Onega & 212 & 1.03 & 0 & 5.3 & 2.29 & 0.34 & 0.59 \\
\hline 24 & Petrun & 215 & 0.85 & 0.15 & 4.9 & 1.78 & 0.53 & 0.22 \\
\hline 26 & Sura & 284 & 1.15 & 0 & 5.92 & 1.2 & 0.47 & 0.3 \\
\hline 27 & Syktyvkar & 325 & 1.42 & 0 & 5.94 & 1.15 & 0.51 & 0.49 \\
\hline 32 & Ust-Usa & 136 & 1 & 0 & 5.88 & 1.3 & 0.29 & 0.36 \\
\hline 33 & Ust-Tsilma & 111 & 1.61 & 0 & 5.44 & 3.63 & 0.33 & 0.48 \\
\hline 34 & Ust-Shchugor & 164 & 1.04 & 0 & 5.25 & 5.62 & 0.35 & 0.27 \\
\hline 35 & Ukhta & 263 & 1.79 & 0 & 5.96 & 1.01 & 0.36 & 0.39 \\
\hline 36 & Khorey Vere & 186 & 1.11 & 0 & 5.67 & 2.14 & 0.47 & 0.36 \\
\hline 37 & Cherepovets & 304 & 1.33 & 0 & 6.18 & 0.66 & 0.45 & 0.34 \\
\hline 39 & Shenkursk & 497 & 1.25 & 0 & 6.18 & 0.66 & 0.48 & 0.26 \\
\hline 40 & Shoina & 302 & 1.25 & 0 & 6.07 & 0.85 & 0.15 & 0.61 \\
\hline 41 & Yarensk & 400 & 0.99 & 0.01 & 5.51 & 3.09 & 0.22 & 0.63 \\
\hline 42 & Amderma & 73 & 0.83 & 0.17 & 5.31 & 4.9 & 0.13 & 0.75 \\
\hline
\end{tabular}

Table 4. Comparison between actual and critical loads for sulphur, $\mathrm{kg} / \mathrm{km}^{2} *$ year.

\begin{tabular}{|c|c|c|c|c|}
\hline Cipher & Station & $U_{a c t . i, \quad \mathbf{~} g / \mathbf{k m}^{2 *} \text { year }}$ & $U_{c r . i, \mathbf{k g} / \mathbf{k m}^{2} * \text { year }}$ & ${ }_{\Delta} U_{i}=U_{c r . i}-U_{a c t . i}, \mathbf{k g} / \mathbf{k m}^{2} *$ year \\
\hline 4 & Bugrino & 351 & 330 & -21 \\
\hline 5 & Belozersk & 499 & 860 & 361 \\
\hline 6 & Upper Toima & 432 & 440 & 8 \\
\hline 8 & Vologda & 423 & 1260 & 837 \\
\hline 9 & Bits. Bereznik & 248 & 760 & 512 \\
\hline 12 & Irayel & 195 & 320 & 125 \\
\hline 15 & Kozhim Mine & 548 & 320 & -228 \\
\hline 17 & Kotlas & 296 & 530 & 234 \\
\hline 18 & Konosha & 520 & 820 & 300 \\
\hline 19 & Mezen & 267 & 450 & 183 \\
\hline 21 & Naryan-Mar & 245 & 390 & 145 \\
\hline 22 & Okunev Nose & 208 & 350 & 142 \\
\hline 23 & Onega & 212 & 710 & 498 \\
\hline 26 & Petrun & 284 & 440 & 156 \\
\hline
\end{tabular}


Table 4. contd...

\begin{tabular}{|c|c|c|c|c|}
\hline Cipher & Station & $U_{a c t . i, \quad \mathbf{k g} / \mathbf{k m}^{2} * \text { year }}$ & $U_{c r . i, \mathbf{k g} / \mathbf{k m}^{2} * \text { year }}$ & ${ }_{\Delta} U_{i}=U_{c r . i}-U_{a c t . i}, \mathbf{k g} / \mathbf{k m}^{2 *}$ year \\
\hline 32 & Syktyvkar & 136 & 320 & 184 \\
\hline 33 & Ust-Usa & 111 & 350 & 239 \\
\hline 35 & Ust-Shchugor & 263 & 340 & 77 \\
\hline 36 & Ukhta & 186 & 400 & 214 \\
\hline 37 & Khorey Vere & 304 & 1260 & 956 \\
\hline 40 & Shoina & 302 & 240 & -62 \\
\hline 41 & Yarensk & 400 & 410 & 10 \\
\hline
\end{tabular}

Calculations for a longer period until 2013 demonstrates the field with hydrogen ion content close to the equilibrium value $(\mathrm{pH}=5.5-5.6)$ covers most of the North of the Russian Plain and apparently represents the natural background in the absence of a notable human-induced impact and natural phenomena such as alkaline soil dust and loose rock weathering products. However, further research is necessary to identify the causes of repeated precipitations with $\mathrm{pH}$ below 5.6 at a local point in the Pechora river basin and also to find out why the actual loads are higher than the critical values developed by EMEP on the Arctic Ocean coast.

\section{CONCLUSION}

The period from 1988 to 2013 shows a trend of lowering (approximately by a half) pollutant emissions from stationary sources in the cities of the northern Russian Plain. The comparison of statistic report data on pollutant emissions in the cities showed a lack of adequate consistency with the trends of atmospheric air quality variations in the cities in the North of the Russian Plain. Despite a significant reduction in emissions, the atmospheric air pollution level in the cities remains high, considering the toxicity of the pollutants.

The highest repeatability of precipitations with $\mathrm{pH}<5.6$ during 1994 - 2004 was recorded in the following areas: 1) local point in the Pechora river area; 2) area of mid-stream Northern Dvina river; 3) local areas of the Arkhangelsk agglomeration, Cherepovets, Vorkuta. In general, the spatial distribution of precipitations with lower $\mathrm{pH}$ has a localized nature.

The content of effective strong acids in atmospheric precipitations and snow cover occasionally becomes visible both in space and time at $\Sigma^{+} / \Sigma^{-}$ratios 0.83 to 1.04 . At a $\Sigma^{+} /$ $\Sigma^{-}$ratio in the specified range, $17 \%$ of precipitations fail to be neutralized during the winter period and $15 \%$ of liquid precipitations are not neutralized during the warm period.
The comparison of the calculated sulphur fallout loads and EMEP's critical loads for the given region showed that the critical loads were not exceeded in most parts of the northern Russian Plain territory. The critical loads may be exceeded in the coastal areas which is likely to be associated with natural processes.

\section{CONFLICT OF INTEREST}

The author confirms that this article content has no conflicts of interest.

\section{ACKNOWLEDGEMENTS}

The author is grateful to V.N. Vasilenko and G.M. Chernogaeva from the Global Climate and Ecology Institute of the Hydromet Agency and RAS for the scientific comments and discussions.

\section{REFERENCES}

Bashkin, V \& Kozlov M (1995) Critical loads of nutrient nitrogen for various ecosystems of russia, mapping and modelling of critical loads for nitrogen: a workshop report, In: Sutton, M (Ed), Proceedings of the Grand-Over-Sands Workshop, 24-26 October 1994, Institute of Terrestrial Ecology, UK, p. 185.

EMEP Co-oprative Programme for Monitoring and Evaluation of the Longrange Transmission of Air Pollution in Europe (2001) EMEP Manual for Sampling and Chemical Analysis, Norwegian Institute for Air Research, Norway, 1-1.

Mapping and Modelling of Critical Loads for Nitrogen: a Workshop Report (1995), In: Sutton, M (Ed), Proceedings of the Grand-Over-Sands Workshop, 24-26 October 1994, Institute of Terrestrial Ecology, Uk.

National Acid Precipitation Assessment Program Report to Congress: An Integrated Assessment (2005) Executive Office of the President of the United States, National Science and Technology Council, Washington, p. 45.

Nilsson, V \& Grennfelt, P (1988) Critical Loads for Sulfur and Nitrogen: Report from a Workshop Held at Stockloster. UN/ECE and Nordic Council of Ministers, Kopenhagen. 
Pidwirny, M (2006) Acid Precipitation. Fundamentals of Physical Geography, $2^{\text {nd }} \quad$ Edition. http://www.physicalgeography.net/fundamentals/8h.html

Markelov, VA, Andreev, OP \& Kobylkin DN, (Eds.) (2013) Sustainable Development of Gas Industry, Nedra, Moscow.

Trubitsina, O (2002) Global/regional acid deposition, In: Shvartsman, Yu (ed), Ecology of the Northern Territories in Russia. Problems forecast of the situation, the development, solutions, Proceedings of the International Conference, Arkhangelsk, 1, 399-403.
Trubitsina, O (2013) Loads of acid deposition in the north of the Russian plain. Vestnik NArFU, Series of Natural sciences, 4, 44-9.

Trubitsina, O \& Shvartsman, Yu (2007) Geoecological condition of atmospheric air in the North of the Russian Plain. Vestnik the Arkhangelsk State Technical University, Series Applied Ecology, 70, 15163.

Vasilenko, VN, Nazarov IM \& Fridman, ShD (1992) Monitoring of acid deposition. Journal of Meteorology and Hydrology, 9, 46-50.

(C) Olga Trubitsina.; Licensee Bentham Open.

This is an open access article licensed under the terms of the Creative Commons Attribution Non-Commercial License (http://creativecommons.org/ licenses/by-nc/3.0/), which permits unrestricted, non-commercial use, distribution and reproduction in any medium, provided the work is properly cited. 